\title{
26 Resarach Soure \\ Catching lung cancer early using only a sample of blood
}

Callum P. Rakhit

Ricky M. Trigg

John Le Quesne

Michael Kelly

Jacqueline A. Shaw

Catrin Pritchard

L. Miguel Martins

\section{Video Byte}

Keywords: lung cancer, blood, diagnostics, detection, biomarker, screening, Disease Models and Mechanisms, KRAS, mouse, circulating free DNA

Posted Date: September 20th, 2019

DOI: https://doi.org/10.21203/rs.2.15144/v1

License: (c) (i) This work is licensed under a Creative Commons Attribution 4.0 International License.

Read Full License 


\section{Abstract}

Lung cancer is the number one cause of cancer-related death Early detection is key to beating the disease A lung tumour that's detected early, before it grows too large or spreads to other parts of the body, can be removed by surgeons and essentially cured The problem is that early detection is tricky Most patients don't develop symptoms until advanced disease has set in, and the most common screening methods can be expensive and impractical Scientists are working on a new blood test that could help The test can spot small bits of DNA floating around in the blood Cancer cells shed this DNA as they grow and multiply Preliminary tests in mice showed the test can detect lung tumours before they become malignant The amount of tumour DNA found in the blood went up as tumours grew, giving scientists an idea of how large a mass had become More work is needed before the test can be used to detect cancer in humans But the research suggests that spotting early-stage lung cancer may one day be possible using only a sample of blood Rakhit, CP. Early detection of pre-malignant lesions in a KRAS G12D-driven mouse lung cancer model by monitoring circulating free DNA. (2019) Disease Models and Mechanisms 